\title{
Our Calendar Stopped! The Organizational Change at UFPB due to COVID-19
}

\author{
Nosso Calendário Parou! A Mudança Organizacional na UFPB devido à \\ COVID-19
}

Discipline: Organizational Behavior, Management Development Subject: Organizational Change, Decision Making Industry: Higher Education, University

Geography: Paraíba/Brazil
Diana Lucia Teixeira-de-Carvalho' ${ }^{10}$ Jose Jorge Lima Dias Junior ${ }^{1} \odot$ Ana Carolina Kruta-Bispo ${ }^{10}$

\section{INTRODUCTION}

It was late afternoon, and whoever was at the Federal University of Paraíba (UFPB) that day had already noticed that the flow of people circulating has decreased. The suspension of classroom activities for the 2019/2 semester has just been communicated, which would end on April 1. But it was still March. More precisely, March 16, 2020. The recommendation of social distance due to the COVID-19 pandemic has reached Paraíba, and the university dean, Margareth Diniz, first weighted decision was to follow it, although it mainly impacted the progress of undergraduate classes.

After a week, the pro-dean of graduation, Ariane Sá, was concerned. The UFPB, because of its size and number

1. Universidade Federal da Paraíba, Centro de Ciências Sociais Aplicadas, Departamento de Administração, João Pessoa, PB, Brazil.

Cite as: Teixeira-de-Carvalho, D. L., Dias, J. J. L. Junior, \& Kruta-Bispo, A. C. (2021). Our calendar stopped! The organizational change at UFPB due to COVID-19. Revista de Administração Contemporânea, 25(spe), e200249. https://doi.org/10.1590/1982-7849rac2021200249.en of people circulating, could have its face-to-face activities suspended for a longer time. The prediction of social distance due to the high contagion of the disease in just 15 days could not apply to the reality of an organization like UFPB. Therefore, it really was needed to think ahead. With that in mind, she summoned an emergency online meeting with the team. "Guys, we need an action plan to use if the suspension of UFPB's face-to-face activities extends indefinitely. I have been talking to the university president and we thought about proposing a special calendar, but I don't know how that would be. We need to mature this idea."

JEL Code: A20, H12, D91 Editor-in-chief: Wesley Mendes-da-Silva (Fundação Getulio Vargas, EAESP, Brazil) (1) Associate Editor: Paula C. P. de S. Chimenti (Universidade Federal do Rio de Janeiro, COPPEAD, Brazil) (1) Guest Editor: Leonardo Marques (Universidade Federal do Rio de Janeiro, COPPEAD, Brazil) (c) Reviewers: Ana Luiza Szuchmacher V. Lopes (Universidade Federal do Estado do Rio de Janeiro, Brazill) tit One of the reviewers chose not to disclose his/her identity.

Peer Review Report: The disclosure of the Peer Review Report was not authorized by its reviewers.

Received: July 13,2020 Last version received: December 11, 2020 Accepted: December 16, 2020

\begin{tabular}{|c|c|c|c|c|c|c|c|c|c|}
\hline & 1 & 2 & 3 & 4 & 5 & 6 & 7 & 8 & 9 \\
\hline $1^{\text {st }}$ round & & p & & & & & & & \\
\hline $2^{\text {nd }}$ round & 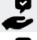 & & & & & & & & \\
\hline $3^{\text {rd }}$ round & & & & & & & & & \\
\hline
\end{tabular}


The team knew this would not be easy, since numerous problems were already being identified in the course of the rest of the semester, which at that time needed to end remotely. Many professors did not know how to use the Virtual Class module of the Sigaa (Integrated Management System for Academic Activities) Platform, which made it difficult to carry out the activities; others still needed to apply tests of the last unit of the academic period or even final tests.

Not to mention the students. There was no certainty that everyone was in conditions to finish the semester remotely, let alone start a special calendar. In addition, the complexity of UFPB's processes was something that could not be ignored. Even so, everyone agreed that they should not just let time go by, and they were committed to developing an unprecedented and audacious proposal.

Many meetings took place in the subsequent 45 days of the conversation between Ariane and her team. Apparently, the initial resistance, which naturally accompanies the proposal of something never done before, has started to decrease, and meetings with the forum for undergraduate advisors from all UFPB centers became more productive.

One of the issues that concerned the most was what to offer in calendar terms. Would that be a regular semester? Would it be mandatory for professors and students? Should it have another format? All of these options were considered, until the possibility of offering a shorter calendar was defined, half the regular one, with no obligation for professors and students.

And what about the disciplines? Would they be curricular components or free courses? Until, in a joint effort, that gathered a lot of information from all courses, through the center's advisors and research conducted by the Graduation Data Observatory (ODG), PRG's advisory sector, Ariane decided to propose what happened to be called the Supplementary Calendar.

A fast, but exhausting path had been taken so far; still, there was much to be done. Several other challenges needed to be overcome, and the main one was how to make this proposal work.

\section{THE UFPB, PRG, AND ODG}

UFPB, an autonomous institution of teaching, research, and extension regime, linked to the Ministry of Education (MEC), developed a multicampus structure, with activities disseminated in four campuses installed in the cities of João Pessoa, Areia, Bananeiras, and North Coast (Rio Tinto e Mamanguape), all of them organized in 16 centers with 120 graduation courses, 80 graduation programs, 2,700 professors, and 37,000 students. To deliver teaching, research, and extension services to society, UFPB has its management formed by the rectory, eight prorectories, the Information Technology Superintendence (STI), and the Distance Education Superintendence (Sead), each composed by their respective teams.

In addition, as it is a public institution, UFPB decisions are always collegiate. There are three deliberative bodies, which are the Higher Council for Education, Research, and Extension (Consepe), which decides on matters of an academic nature; the University Council (Consuni), the highest decision-making body in the field of general policy at the university; and the Curator Council, a fiscal and deliberative body in economic and financial matters at the university.

Specifically on teaching activities for undergraduate students, the Office of the Pro-Rectory of Graduation (PRG) has the mission of "proposing, coordinating, and executing academic policies and supervising the teaching activities of undergraduate courses," the pro-dean of that administration being Professor Ariane Sá. One of the actions implemented by Ariane was the creation of the consultancy that gave rise to the Undergraduate Data Observatory (ODG), in order to collect, select, and disseminate evolutionary data about the undergraduate course's situation, coordinated by Professor Jorge Dias. Since 2018, the sector acts on the development of indicators and analytical applications to assist PRG in making data-based decisions. This has extended to the pandemic scenario faced by UFPB at that moment.

\section{COVID-19 AND THE SUPPLEMENTARY CALENDAR}

When the pandemic impacts caused by COVID-19 reached UFPB, the graduation was ending the 2019/2 calendar. The regularization of school periods was expected to be in 2020 so that the $2020 / 1$ semester would be from April to August and 2020/2 from August to December. Since 2017, professors and students, coordination, and departments have worked for three periods per year so that, within three years, the graduation calendar could be normalized, due to the strike that occurred in 2015.

However, this planning should not be maintained. Since around 40 thousand people circulate daily at UFPB, in all its campuses, the institution became a place of high risk of COVID-19 contamination. Added to this was the concern that many of these people belonged to the classified risk group and they would be more vulnerable, which was difficult to map immediately. Thus, no matter how strategies were formulated to reduce the approximation between students and professors, social isolation was indispensable at that time. 
The 2019/2 semester was supposed to end remotely, and this was defined based on the expectation that social isolation could last at least two months, so that interrupting the calendar for that much time would also represent a loss for the academic community, which already had the schedule of classes in relative delay. However, this decision revealed a worrying panorama in terms of execution, because there was a large number of professors who were not familiar with the Sigaa Virtual Class module, and who were unable to perform distance activities, such as the semester's last unit exams or the finals.

The final period of the 2019/2 calendar of the undergraduate program was extended to April 18, in order to avoid further damage to the professors' performance caused by this transition from face-to-face to remote. As for the students, exceptional cases should be analyzed and resolved, so that everyone could finish the semester remotely.

Undergraduate activities, which started the 2020/1 calendar at the beginning of March, as well as research and extension activities, have not stopped, adhering to online tools. With that, the Pro-Rectories of Undergraduate Studies (PRPG), Research (Propesq), and Extension and Community Matters (Prac) were acting with certain normality, monitoring possible difficulties and adaptation needs.

The PRPG even requested the Pro-Dean for People Management (Progep) to offer training for programs of graduate professors in order to minimize the difficulties of handling UFPB digital platforms in the remote continuation of the 2020/1 semester. In addition, the coordinators of the ten distance courses, together with Sead, decided to continue their activities.
The situation of face-to-face undergraduate courses was different, and PRG faced a scenario of uncertainty. After all, with the end of the 2019/2 calendar, should the undergraduate classes be suspended while the social isolation decree lasted? With the thought that it was opportune to plan alternatives, even in March, Ariane gathered the coordinators of her team, summoning them to discuss together.

It was a big problem, mainly because, until then, only the Federal University of Lavras (UFLA) maintained its undergraduate classes remotely. All other federal universities had suspended the semester, in a context that did not yet have a regulation of the federal government itself about how the activities should work.

The PRG team had been doing a daily analysis of everything that was being published, such as MEC ordinances and drafts from the National Education Council, to understand the national guidelines for universities, but there was nothing concrete. In fact, practically all managers of the federal universities were not knowing how to act, including because there are legal issues related to the current guidelines of the MEC and LDB (Law of Guidelines and Bases of National Education) on offering disciplines at a distance and this, by itself, already limited a different performance than expected.

The federal government provided, through the MEC website, analytical panels for the society to follow which federal educational institutions were with their activities suspended. The general panel (Figure 1) presented the numbers of the entire Federal Education Network, composed of universities and federal institutes, Cefets, and Pedro II School, indicating how many were still with suspended activities.

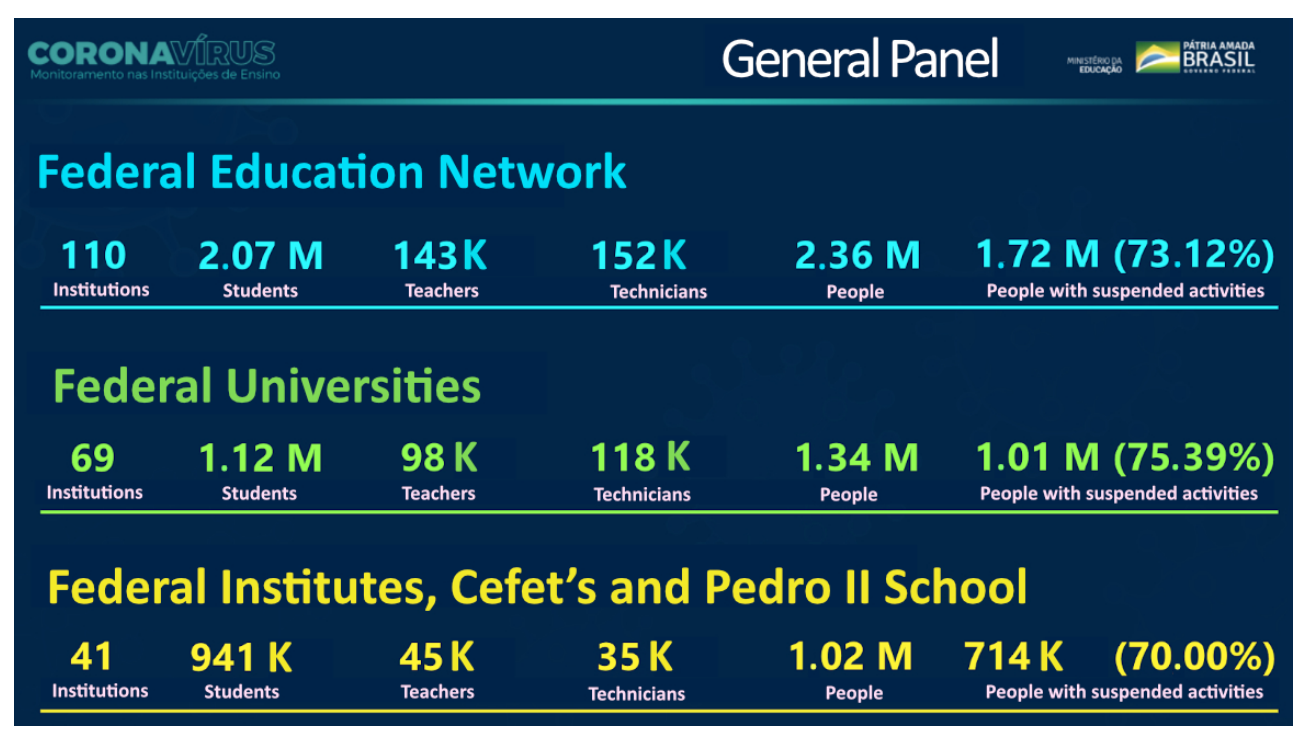

Figure 1. General panel of monitoring of the federal education network.

Source: Brasil (2020). Ministério da Educação. Coronavírus: Monitoramento nas Instituiçōes de Ensino. Retrieved from http://portal.mec.gov.br/coronavirus/ 
In particular, the minister of Education, on April 20, published in his personal Twitter account a post (Figure 2), as well as released, also on social networks, a video with a message that related to the same image of such post: "Here in the blue part, the universities are already fully functioning. They have already resumed their activities remotely or in person. In yellow partially resumed the part of the courses, in red we will have to run after to see why the undergraduate students did not return. Keep up, you'll see this place will turn green and yellow. That red will disappear in another week or two."

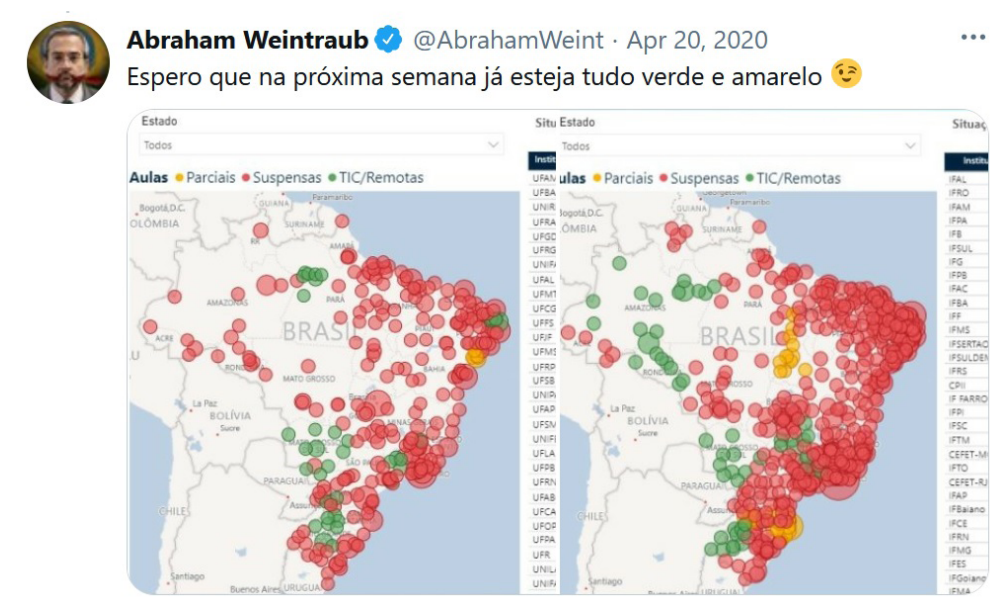

Figure 2. Tweet from the minister of Education and Citizenship.

Source: Twitter. Tweet translation: "I hope next week everything will be green and yellow."

This was the external scenario that the public institutions were experiencing. Regardless, Ariane maintained the idea that the UFPB could be one of the avant-gardes in presenting a response to this unexpected situation, even being aware of the difficulties. If the conclusion of the 2019/2 period, although with so many obstacles narrated and faced by professors and students, was happening, how could we not think of alternatives to at least start the 2020/1 semester?

At that time, a month had already passed since the beginning of social isolation, and now there was no forecast of face-to-face return. It was essential to consider the feasibility of a model that would enable professors to feel safe to operate. A major concern, from the beginning, was the reaction of professors who needed to learn how to act remotely, but Ariane trusted that the UFPB faculty would be willing to face the challenge.

Given this scenario, Ariane understood that the group with which the PRG should start the talks and expand the knowledge on the possibilities of implementing this remote calendar was the forum composed of 16 undergraduate advisors of the UFPB centers, with whom her team met every Monday since 2013. In these discussions, it was possible to gradually understand how each center was positioned, how there could be the acceptance of a calendar with an alternative model never made before in the UFPB, and what actions could be undertaken, given the idiosyncrasies of each course.

\section{FIRST QUESTIONS AND THE NEED FOR A DIAGNOSIS}

Initially, there was a recurrent resistance when talking about any kind of calendar for graduation with distance lessons. The courses would turn into e-learning? Arguments soon emerged about this not being the UFPB proposal, emphasizing that classroom teaching could not be replaced, only supplemented with distance activities. Undergraduate advisors insisted that distance education for in-person courses was something that would go against the resolutions and guidelines of the MEC.

Faced with this concern, the PRG team, after understanding that the term 'distance learning' caused confusion during the first meeting with the undergraduate advisors, researched types of teaching with the characteristics they were facing and began to use the appropriate term. On that April 20, it was the second meeting that took place and, when the buzz rekindled the discussion about e-learning, one of the PRG coordinators asked for the floor, interrupting it: "This is not e-learning, as it has an already consolidated and organized structure. The professors who teach in e-learning are trained to 
prepare content and pedagogical resources in this modality and rely on the action of tutors who help and support them in the teaching-learning process. In addition, there is a regulation of its own, so it is not because we are using remote technologies that we are dealing with e-learning. The term that the literature has been using is 'emergency remote teaching.' It's remote because it needs to be applied non-face-to-face, and it's emergency because there was no planning for such a sudden transition. That's not a new term. Countries, for example, that experienced civil war, adopt this model. The premise is that teaching should not stop and that's what we did for the continuation of the 2019/2 calendar," he explained.

From this meeting, it was defined that the PRG team would use the concept of 'emergency remote teaching' in documents and meetings, avoiding any confusion generated by the term 'distance education' (e-learning). However, that was just one of the questions that Ariane and her team had heard during the meetings. Another that caused some uproar concerned the possible inaccessibility of students to the internet, since, in the disclosure made to the academic community by email, a newsletter revealed that $42 \%$ of students lived in a vulnerable situation by having family income of up to two minimum wages. The possibility that a calendar offered during the period of social isolation might generate inequality was a stalemate that soon emerged: "Ariane, what about socially vulnerable students? How will they be included?" asked one of the undergraduate advisors. "Not to mention students with special needs. If, many times, it is difficult for them to follow the classroom classes, how will we do if they are remote?" amended another.

At the same time, without a definition of what the proposal would be, there was a polarization: on the one hand, it was argued that, if a single student did not have access to any kind of offer, UFPB would be reinforcing inequality; on the other hand, the pressure to offer a regular calendar was made by some centers. Therefore, after this meeting, Jorge suggested: "Ariane, we need to have a diagnosis about the profile of students. What do we know about their ability to take remote lessons? Nothing! Suddenly, $42 \%$ of students have a family income of up to two minimum wages turned to not have access to the internet?! Regardless of the result, decisions, actions, and strategies need to be data-driven." "Yes, Jorge! I think it is fundamental," Ariane agreed.

Based on this conversation, Jorge was responsible for conducting a research that the PRG would offer as a diagnosis to clarify the possible impacts that an alternative format calendar would represent for students. To provide the academic community with an institutional survey that could support decision-making, the ODG developed a questionnaire to diagnose the profile of internet access and remote technologies of UFPB students.

However, this was another process that met some challenges, because before the ODG could apply it, several other institutions of the UFPB (course coordinators, student academic centers, the Central Student Directory, etc.) applied their own questionnaires and published their results. Therefore, many of these entities, in addition to the result, decided to be in favor or not of a period with remote activities.

One of these reports was published by the Student Academic Center of one of the UFPB courses. The survey made available via Google Forms obtained 296 responses, which represented $64.35 \%$ of the total number of students. Also, according to the report, $97.3 \%$ of students lived in an urban area. Of those who lived in rural areas, $50 \%$ had no computer and $12.5 \%$ had no cell phone. In addition, of the total number of students who answered the questionnaire, $1.35 \%$ did not have internet access.

According to the report, this point would highlight the ineffective institutionalization of remote activities. In the end, the report revealed its position contrary to the implementation of remote activities, since it would benefit only a portion of the course. This was only one of several results obtained by these parallel researches to the ODG, and many presented the positions of the entities that applied them in relation to a remotely executed period.

At the same time, the ODG prepared the instruments to carry out the institutional research, based on a careful set of concepts. With this concern, Jorge invited some professors with experience in quantitative research to validate the questionnaire that should be answered by the students. Another decision was to operationalize the answers through the official platform of UFPB, Sigaa, which would guarantee authenticity, because only students of UFPB would respond, and uniqueness of the answers, which would prevent a student to register more than one answer.

With the questionnaire ready, still in April, students were mobilized to respond via communication in Sigaa and through various social networks linked to UFPB. However, the time was short, because many institutional units were waiting for the results of the research to position themselves. It was also important that these data could guide the decision-making of the PRG with the other entities of the university.

The period of application of the research was therefore only one week, and many students had already answered the questionnaires of other entities. Even though, more than 14 thousand undergraduate students 
responded, which represented about $60 \%$ of the students who on average enroll in a regular semester.

Unlike the online research conducted by the other UFPB entities, ODG operated the crossing of data from the questionnaire with socioeconomic data to ensure the representativeness of the sample. With this, Jorge verifies that most respondents had up to two minimum wages (Figure 3) and came from public schools (Figure 4), which was in line with the socioeconomic characteristics of the total number of students in the institution.

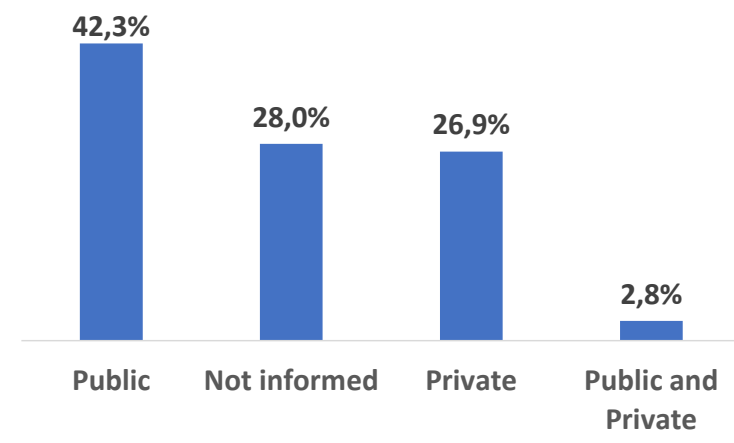

Figure 3. Students' home school.

Source: Observatório de Dados da Graduaçáo. Dados da pesquisa do ODG. Retrieved from https://linktr.ee/odg prg ufpb

\begin{abstract}
0 to 2 minimum wages
2 to 4 minimum wages

4 to 6 minimum wages

6 to 8 minimum wages

8 to 10 minimum wages

10 to 12 minimum wages

12 to 14 minimum wages

14 to 16 minimum wages

16 to 18 minimum wages

18 to 20 minimum wages

Above $\mathbf{2 0}$ mininum wages

Not declared

$2,3 \%$

$1,5 \%$

$1,6 \%$

$0,3 \%$

$0,2 \%$

$0,6 \%$

$0,1 \%$

$1,0 \%$

Figure 4. Students' family income. https://linktr.ee/odg prg ufpb
\end{abstract}

$33,2 \%$

$15,5 \%$

\section{$6,1 \%$}

$37,6 \%$

Source: Observatório de Dados da Graduação. Dados da pesquisa do ODG. Retrieved from
When analyzing the data, Jorge also identified that $84 \%$ of respondents had a computer or notebook for their academic activities and that $90 \%$ had broadband internet access. This percentage reached $99 \%$ when it came to some type of access so that $98 \%$ accessed the internet every day or almost every day. However, the data revealed that $91 \%$ of respondents were able to watch videos online and $91 \%$ were able to read a text in any format (Figure 5). 


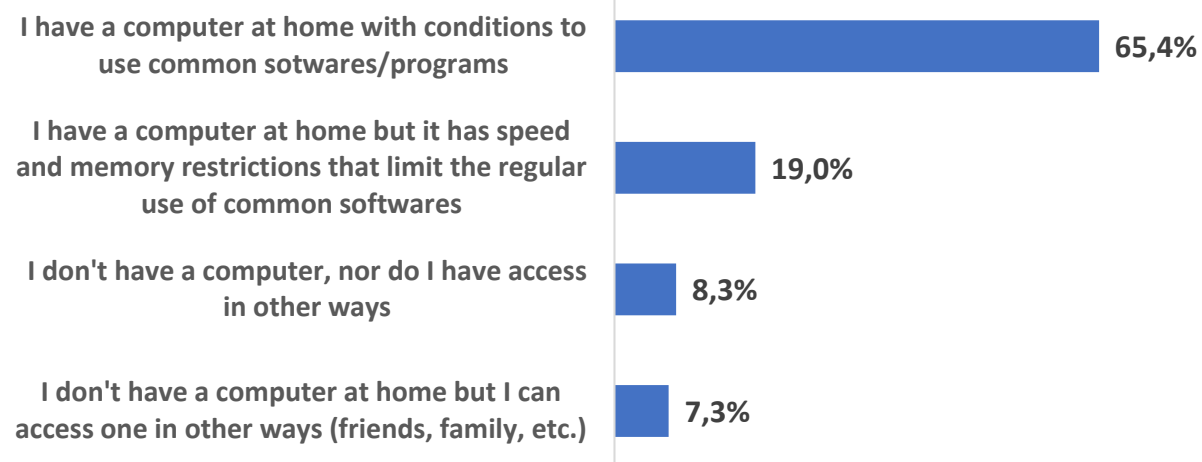

Figure 5. ICT access profile.

Source: Observatório deDadosda Graduaçáo. DadosdapesquisadoODG. Retrieved from https://linktr.ee/odg prg ufpb

In addition, the research revealed that $76 \%$ of students indicated that they would probably participate in remote activities if their course offered them during social isolation. On the contrary, a percentage of $14.4 \%$ answered that they would not be interested and $11.5 \%$ of the students were indifferent. Finally, ODG obtained the information that, of the students with up to two minimum wages and who came from public school, $80 \%$ had a computer or notebook; $84 \%$ had broadband internet access; and 99\% had some kind of connectivity. As a result, $68 \%$ of students with this profile stated that they would participate in remote activities during social isolation if there were any.

As of early May, Jorge presented the data in several meetings until arriving at the Consepe. In addition, he has developed and made available analytical panels, which allowed the academic community to explore the data through various filters. The results, to a large extent, surprised the community, especially about the percentage of students who have internet connectivity and computer access. Even so, at the meeting with Consepe, one of the councilors asked: "What about the other $40 \%$ ? Where are they?" Those were questions that kept coming back.

\section{FACING NEW CHALLENGES, WHAT TO DECIDE?}

Almost two months had passed. It was early May and Ariane would like to start the supplementary calendar in June at the latest, after all, students and professors were out of class at graduation since April. At that time, Ariane and her team were already participating in meetings with the center councils, in addition to those regularly held with the graduation advisors. With this, the PRG had drafted the preliminary version of a draft resolution, even knowing that it could still change a lot when submitted to the Consepe and its 44 full members.
In fact, the great challenge was to have a consensus in the academic community about the proposal. Some departments and courses were reluctant to accept a supplementary calendar. By now, the PRG team had already thought about the optional character that this period should have, for both professors and students. This was because it considered the professors' workload, which could not exceed 40 hours per week, since many had not stopped the activities, acting in research and extension, and the impossibility of requiring all students to be able to study subjects remotely.

In any case, the format was defined. The supplementary calendar would last ten weeks and the courses offered could be free or of curricular components. However, there were still many issues that were generating insecurity in the faculty. Several entities and class associations released notes with a position contrary to a possible supplementary calendar and, even if this context was not enough to discourage the PRG team, as the meetings progressed, new possible problems were being listed: "Dear colleagues, we need to consider that our professors are prepared to teach classes in person and not to teach remote classes!" complained Roberto, a professor for 28 years in the institution. "Also, developing materials for remote classes, without being prepared, will require many more hours of work. I'm worried. How will our weekly workload be?” asked Professor Amália.

"Another problem that needs to be considered is that the Sigaa Virtual Class module does not have the necessary resources to teach remote classes properly! I believe that it is a support tool only," highlighted Professor Maria, who also worked in an e-learning course at the institution. "Guys, are you considering that many professors have children? How will you be able to teach with the children at home?" Professor Inácio reminded them.

Faced with so many questions, Ariane pondered: "I understand the questions presented, ladies and gentlemen, but we need to do something. We must remember that this 
is a period of exceptionality, that chaos generates change, generates possibilities, and this is what we are trying to do here. The research and the extension didn't stop. How will teaching be? We need to consider the need to provide an answer to society if the suspension of face-to-face activities is extended. I know that we need to have more information to move forward and that our discussions must be polished, but we will take all the care that the situation requires and we know that our professors are enthusiastic and engaged with our community," she said in a pragmatic way, which calmed the spirits at the meeting.

However, Ariane could not ignore the obstacles. She knew that the concerns expressed in the endless meetings needed to be resolved so that an emergency remote learning calendar could work. The vast majority of professors were not trained for this type of teaching and, even though Progep had offered some training courses during the 2019/2 calendar, almost $90 \%$ of the professors who enrolled had dropped out. In operational terms, how would the professor act based on the use of remote tools, especially given the plurality of skills, which ranged from a recurrent use to a complete lack of intimacy with this type of tool?

There were also professors who credited the evasion of the courses promoted by Progep to the difficulty with the handling of Moodle. Sigaa, not having all the necessary functionalities for remote teaching, would need to be replaced by another more complete platform. In this sense, the training of Moodle, Virtual Learning Environment (AVA), used by e-learning, for all the professors of the graduation courses, with several classes composed of more than 100 professors to be trained, began.

Nevertheless, the system was not intuitive and the tasks were difficult to accomplish, which caused the deadlines for closing the courses to be extended at least twice in a period of two months. Even so, the result was a high dropout of professors. This signaled two more difficult problems to be dismissed. The training of professors to teach remotely needed to be effective and the official platform for carrying out a supplementary period more attractive.

In this context, how can the supplementary period be made operational? Ariane's concern has always been to continue providing service to society. Even aware of the difficulties for an institution like UFPB to be quickly adapted to an unexpected scenario, she tried to remain confident that it would be possible, in an exceptional way, to offer classes again for undergraduate courses.

However, the further they went, the more obstacles arose. Was it still necessary to convince the academic community of the meaning of an additional calendar? How to prepare the UFPB's diverse faculty in time? What about the infrastructure, would the current tools be suitable for the needs of the remote period? Would the academic management system be able to support a special period? What would the enrollment process look like, for example?

At the end of a week of many meetings, in which so many questions were presented, the last one was with the group of graduation pro-deans of the public institutions of Paraíba. In it, the pro-deans discussed the possibility of a calendar of remote activities in these institutions, but still in a speculative way, when at UFPB they had already advanced to the writing of a draft resolution. However, this made Ariane reflect. Faced with all these other challenges, would it be better to try to continue the implementation of the supplementary calendar at the UFPB or to back off and wait for other public institutions to mobilize so that the PRG team could base itself on some model and facilitate this process? 


\section{Teaching Notes}

\section{ABSTRACT}

This teaching case aims to analyze the context of the Federal University of Paraíba, which experiences the impacts of social isolation due to COVID-19, especially in conducting undergraduate classes, considering that the activities face-to-face were suspended. The case presents the facts related to the possibility of implementing a supplementary calendar, based on the concept of remote emergency teaching. Because of this scenario, the Pro-Rectory of Graduation managers needed to plan carefully to manage the uncertainties and resistance to changes that such a proposal would represent, mainly because there were no models to be based on since practically all public HEIs have suspended graduation classes. The case raises a significant dilemma: in the face of the challenges of implementing a supplementary remote calendar, is it better to follow or step back? The pedagogical objectives of this teaching case involve: analyzing the impact of COVID-19 on organizational behavior; discuss aspects related to the implementation of organizational changes; identify the use of data for decision-making and support for organizational change; and making decisions in the face of managerial dilemmas. Its analysis can be done by undergraduate students, in Administration and Public Management courses.

Keywords: HEI; organizational change; data-based decision-making; academic management.

\section{EDUCATIONAL OBJECTIVES AND APPLICATION RECOMMENDATIONS}

The teaching case aims to analyze the impact of COVID-19 on organizational behavior, considering that the resulting scenario from the pandemic is composed of numerous uncertainties and the need to adapt of a public HEI. Therefore, it is expected that the case will provide students the following skills: (a) understand the aspects related to the implementation of organizational changes, considering the complexity of a public HEI; (b) recognize the use of data for decision-making and as a support for planning organizational change; and (c) experiencing organizational decision-making in face of inherent dilemmas in the performance of an HEI manager. The case

\section{RESUMO}

Este caso para ensino tem o objetivo de analisar o contexto da Universidade Federal da Paraíba, que vivencia os impactos do isolamento social devido à COVID-19, sobretudo na realização das aulas de graduação, considerando que as atividades presenciais foram suspensas. $O$ caso apresenta os fatos relacionados à possibilidade de implementação de um calendário suplementar, com base no conceito de ensino remoto emergencial. Diante desse cenário, era necessário dos gestores da Pró-Reitoria de Graduação um planejamento cuidadoso para gerenciar as incertezas e as resistências às mudanças que tal proposta representaria, principalmente porque não havia modelos para se basearem, uma vez que praticamente todas as IESs públicas estavam com as aulas de graduaçáo suspensas. $\mathrm{O}$ caso levanta um dilema principal: Diante dos desafios para implementar um calendário suplementar remoto, é melhor seguir ou recuar? Os objetivos pedagógicos deste caso para ensino envolvem: analisar o impacto da COVID-19 no comportamento organizacional; discutir os aspectos relativos à implementação de mudanças organizacionais; identificar o uso de dados para a tomada de decisão e suporte para a mudança organizacional; e tomar decisóes frente a dilemas gerenciais. Sua análise pode ser feita por alunos da graduação, dos cursos de Administração e Gestão Pública.

Palavras-chave: IES; mudança organizacional; tomada de decisão fundamentada em dados; gestão acadêmica.

is recommended to be applied primarily in the disciplines of Organizational Behavior, Management Development, Decision-making Process, People Management, and Educational Management. Additionally, although the analysis of the case does not direct these disciplines, it is possible that aspects related to the Market Research, Human Resources Administration, and Project Management disciplines are identified, depending on the referral made by the professor. The case analysis is indicated, preferably, for graduation courses of Administration and Public Management. 


\section{DATA SOURCES}

The data were obtained primarily from the realization of semi-structured interviews with the main actors of the case, the pro-dean of undergraduate studies of UFPB and the coordinator of the Undergraduate Data Observatory. In addition, data from participant observation, from monitoring online councils meetings and participating in committee meetings formed to face the crisis, such as the professor and student training committee, were used in the preparation of this case. In a complementary way, secondary data obtained from internal reports, from UFPB (Universidade Federal da Paraíba, 2019; 2020) and MEC (http://portal.mec.gov.br/coronavirus/ retrieved on August $12,2020)$ websites, and from social networks were also used. The names of some characters have been changed, but the name of the institution and the protagonists, as well as the facts presented, are all real.

\section{QUESTIONS FOR ANALYSIS}

Question 1. Due to the social isolation caused by the COVID-19 pandemic, UFPB proposed to implement a supplementary calendar to be executed remotely. How do you analyze the organizational change process required in this context faced by UFPB?

Question 2. Consider that every change presupposes resistance. In the case of the implementation of the supplementary calendar at UFPB, how do you assess the manifestations of resistance from the academic community and which actions were or could have been taken to overcome them?

Question 3. Discuss the role of the Undergraduate Data Observatory (ODG) for the decision-making in UFPB's organizational change process.

Question 4. When putting yourself in Ariane's position, as pro-dean of graduation, what would be your decision, to follow or to retreat the supplementary calendar? Provide arguments to justify your choice.

\section{LESSON PLAN PROPOSAL}

Before the beginning of this case analysis, it is indicated that the professor emphasizes the relevance of using a case for teaching in the learning, explaining the relationship between theory and practice that this strategy implies. In addition, it is proposed that the professor request students to conduct a brief survey on the public higher education service, so that they become familiar with the organizational context on screen, in order to stimulate students' engagement and understanding of related topics to the case in general. Still, it is necessary that the professor provides the case and the questions at least one week in advance, requesting the reading and individual answer to the questions.

For conducting the case analysis session, four steps are proposed for a two-hour class:

1. Opening (estimated time: 10 minutes) — The professor can start the session with more general questions, which address the implications of external factors in organizations, such as the COVID-19 pandemic, favoring a type of warm-up to the discussion. About this, questions can be asked such as: In general, what implications are seen in the internal context of organizations due to the pandemic? Which opportunities and threats did organizations face? In addition, the professor can encourage the students to reveal important aspects researched about the public HEIs context.

2. Small groups discussion (estimated time: 40 minutes) - The professor should encourage that, in small groups of three to four people, students discuss the answers to the questions described in the case, analyzing and proposing joint solutions. For this purpose, it is suggested that random groups be separated in order to stimulate debate and develop social and emotional skills, besides technical skills.

3. Large group discussion (estimated time: 40 minutes) - After discussion, it is indicated that each group orally presents its analysis and the dilemma solution faced by the institution, with the professor inciting the debate and encouraging the students participation. The professor must be aware to possible conflicting points, so that he can foster constructive discussion about the topic.

4. Discussion closure (estimated time: 30 minutes) The professor should close the discussion, proposing directions to analysis based on the opinions expressed by the students and discussing the proposed alternatives, being able to use the board to list them, so that results of the discussion are visible to everyone.

Despite the estimated time for each stage, it is understood that, depending on the heterogeneity and the particularity of each class, it is up to the professor to decide the best way to conduct the systematic case analysis. Using the case strategy as an evaluative note may also be at the discretion of the professor. 


\section{CASE ANALYSIS SUGGESTION}

In this topic, the analysis of the suggested questions for discussion of the case is presented, in order to guide the teaching-learning process. It is opportune to reinforce that other questions can be elaborated by the professor, according to the objective of applying the case.

Question 1. Due to the social isolation caused by the COVID-19 pandemic, UFPB proposed to implement a supplementary calendar to be executed remotely. How do you analyze the organizational change process required in this context faced by UFPB?

The case presents a scenario of substantial change caused by an external factor to the organization (university). In this sense, the professor should direct the students to understand the change itself, through its theoretical definitions within the organizational context, as well as to analyze this change process from a broad and systemic point of view. Thus, the professor can use elementary questions to introduce the discussion: What is the change dealt with in the text? What is the reason for this change? The recommendation is that the professor let the class free to define and analyze the change process based on theories involving culture and organizational change seen in previous classes.

Specifically, it is indicated that the professor can be based on one of the classic models of organizational change, provided by Kurt Lewin, in which the change process occurs in three stages: Unfreezing, Moving, and Refreezing. The model emphasizes that effective change runs through defrosting the current situation, changing to a desired condition, so that afterwards a refreezing occurs. Thus, the first stage refers to understanding the need for change, so that the status quo is broken. The second step involves mitigating the factors that generate resistance to change. The defrosting stage, on the other hand, is related to actions so that the change can be lasting (McShane \& Glinow, 2014).

In this way, the professor should encourage that the students present elements that motivate the status quo changes (Unfreezing), making it clear what is the target of change and the need to create an urgency for it, which encourages the coping of the risks associated with this process (McShane \& Glinow, 2014). At this moment, some evidence can be found in the text, such as: external pressure from other institutions (the government itself, for example), the lack of references in the country about adopting emergency remote education in public HEIs, the need to maintain students engaged and involved in the university, reducing the damage to education, among others. Other reasons may arise during the discussion that are not explicit on the text, but that are part of the experienced context.
On the other hand, students should also be made to identify the restrictive forces that encourage the maintenance of the status quo, creating resistance to change (McShane \& Glinow, 2014). It is important to make it clear that an organization, in any process of change, seeks to maintain the current situation, tending to preserve stability (Dias, 2013). At this point, the professor may ask: Why is there a tendency to maintain the status quo? The objective is to highlight the importance of understanding that organizational culture is product of a historical process, of lived and accumulated experiences and that, therefore, it is formed by beliefs, values and behaviors, that serve as a reference for the decisions about the change process. Therefore, the change means to modify or reinterpret these values that are integrated and that, many times, are operating at the unconscious level (Dias, 2013).

In order to make the discussion more concrete, the professor must explore the various aspects involved in organizational changes, both with elements of the case and with others inherent in any change process. Some of these aspects, based on Dias (2013) and which can be explored by the professor, are:

a. All change is essentially a political process that involves power relations, mainly in an organization such as a public institution of higher education;

b. The change process requires the search for a balance between flexibility and rigidity, according to the juncture of the context;

c. The change breaks with stabilized routines, causing fear due to the uncertainties;

d. Changes bring risks that need to be considered;

e. Change processes require time to be internalized, understood, and absorbed by the actors of the organization;

f. The importance of having a working team to guide the change process;

g. The involvement of people in the process is essential to generate engagement and support for the change;

h. Every change process needs to be planned and organized. 
It is also worth considering the organizational size of UFPB, and the consequent plurality of organizational actors, as well as the nature of its processes, which are more hierarchical and bureaucratic, which makes the change considerably more challenging. With that, the teacher can highlight the aspects that pervaded the change in the context experienced by UFPB.

Question 2. Consider that every change presupposes resistance. In the case of the supplementary calendar implementation at UFPB, how do you evaluate the manifestations of resistance from the academic community? Which actions were implemented from the foregoing in the case? What other actions could have been taken to overcome them?

This question is intended to lead students to discuss resistance as one of the main barriers to organizational change. From there, the professor may explore the students' prior knowledge about the processes of resistance to change, asking introductory questions such as: Who has experienced any process of organizational change? Did you notice if there was resistance during the implementation of the change process?

Then, the professor can rely on Robbins (2015), in order to emphasize that, in general, resistance emerges at the individual or organizational level. At the individual level, people usually object to change for reasons such as habits, security, and fear of the unknown. Organizations, on the other hand, because they have a conservative nature, actively resist change through inertia, which may occur in the structure or may arise from the actors who will be impacted.

Thus, the professor may highlight parallels between the concepts presented from Robbins (2015) and the responses brought by the students. The case will help in the discussion as the teacher rescues the dialogues that expose individual resistance, especially when concerns are mentioned such as learning new technologies, working with children at home, not having the necessary platforms, having greater effort to prepare materials in a new teaching model, etc. Meanwhile, the lack of adaptation of the current VLE structure to a more attractive layout and the high evasion rate of teachers in training courses for Moodle tools are configured as examples of organizational resistance.

At this point, knowing the scenario of the change implementation, as well as the resistances arising from it, the professor can explore the students' assessment of the resistances presented, asking questions that lead them to think about strategies to overcome these resistances. For example: How do you assess the individual resistances presented in the case? What about organizational resistances? Can you think of actions to overcome these resistances?

At this point, the teacher can explore Ramos (2017). So that any change process can be considered, under Ramos' perspective, it is necessary for managers to consider implementation strategies, alternative solutions, and ways to overcome resistances to change, starting above all a discussion about the need for change, and leading the students to reflect and recognize their managerial and decision-making role. From this recognition, the professor may introduce the discussion about overcoming resistances. For this, the professor may use the conceptual basis presented by Daft (2008) and Ramos (2017).

To mitigate resistances, Daft (2008) suggests some techniques that can be used in order to be successful in implementing change, such as communication, participation in the change project, negotiation through formal bargaining to gain acceptance and approval, coercion through formal power, and support from top management. In the case, it is possible to identify that several of these actions were carried out by the PRG team, since the many meetings that took place during the decision-making process for the change not only sought to communicate their need, but also initially involve undergraduate advisors, negotiating with them a supplementary calendar format that would achieve approval.

In addition, based on the diagnosis elaborated by the ODG, the evidence brought through the data allowed, to some extent, to reduce the resistance of those who claimed that more than $42 \%$ of students did not have access to remote education due to their socioeconomic profile. In this context, communication becomes an important strategic action, mainly by allowing decision-makers to explore information through available filters.

This also converges with the proposition of Ramos (2017) about strategies to overcome resistances, which are education and communication, employee involvement, the facilitation and top management support, negotiation, cooperation, and coercion. In these strategies, it is possible to identify those that could be better used by PRG to overcome difficulties and achieve commitment, especially from professors.

Beyond the actions implemented, others can be suggested. With regard to education and communication, the professor may lead the students to reflect on the meeting process that took place to resume the calendar and argue that the meetings were limited to specific groups, which excluded most of the academic community. Regarding facilitation and support, it can be recognized the need for effective training so that professors are able to deal with the fear and anxiety associated with the change effort, 
acquiring new skills or abilities. All of these strategies may help overcome initial resistances.

Question 3. Discuss the role of the Undergraduate Data Observatory (ODG) for decision-making in UFPB's organizational change process.

In this question, the professor must explore the discussion about the relevance of communication as a strategy, and about the need to obtain relevant information for decision-making in an organizational change process. This information shall allow a diagnosis of the reality of the situation, serving as an instrument of discussion in the spaces related to the change process.

The case presented the data collected by PRG, through the ODG, in which more than 14 thousand students answered a questionnaire to identify the profile of internet access and to remote technologies. In order to raise the discussion based on this fact, the professor must question the importance of this action for the change process. It should be clear that the diagnosis of this research allowed to clarify some beliefs that were being put forward, for example, the percentage of students in situations of vulnerability (family income and school of origin) who have some type of connectivity and access to the computer/ laptop. In addition, the result showed that at least $3 / 4$ of the students would participate in the supplementary period.

The case shows that there was a misperception about one aspect of reality, which was serving as a restrictive force to the change process, favoring an increase in resistance (Dias, 2013). In this way, the professor must ensure that students understand that the role of ODG was to collect data that allowed greater objectivity to some aspects considered sensitive in the process of organizational change, reducing uncertainties, which generated more security for decision-makers and the academic community in general.

Thus, the information, and the data derived from it, must be of good quality, allowing the conclusions arising, consequently, to raise the quality of decisions. There is a fact in the text that can be explored, concerning the research carried out by a student academic center, which revealed some data that reinforced resistance to change. The professor should use this example to encourage a discussion about the use of data in the debate that permeates the change process, questioning if the students identified problems in the survey carried out by the academic center.

The answer must go toward the method used Google Forms, which, for the data collection, does not guarantee the authenticity of the respondents (since anyone can answer the questionnaire), nor the uniqueness of the answers (since the same person can answer the questionnaire several times). Furthermore, the percentage numbers need to be observed with caution, as they can, to some extent, confuse the decision-maker. In the text example, $2.7 \%$ of students live in rural areas, which represents eight students who participated in the survey. Of these, 50\% do not have a computer, which represents four students; and $12.5 \%$ do not have internet, which represents a single student. It is important to note that the data to guide decisionmaking, in organizations such as a university, will be used for both those who are in favor and those who are against the change process.

Thus, considering that these data are relevant to the decision-making process, attention to methodological planning is essential in order to achieve reliable results based on scientific rigor, which involves concerns such as: the quality of the instrument, the process and collection strategy, sample representativeness, data analysis, and information communication. This methodological planning is illustrated in the case, and the professor may stand out in this process, mainly because the dissemination of data with methodological problems can represent difficulties in the interpretation of reality and, therefore, hamper decision-making and, consequently, the change process.

Question 4. When putting yourself in Ariane's position, as pro-dean of graduation, what would be your decision, to follow or to retreat the supplementary calendar? Provide arguments to justify your choice.

The objective of this question is to exercise the student's ability to stand before a critical decision, as well as to make him reflect on the justifications and possible consequences of that decision. Thus, the student must put himself in the place of the public manager and decide on the dilemma posed in the case. Therefore, the professor must encourage the construction of alternatives for decision-making, considering that, even if there are two main ones (to proceed with the supplementary calendar or to wait), the student may present other alternatives.

With that, the professor must be prepared so that the decision, and its respective justifications, can provoke relevant discussions and expose antagonistic points of view. In this sense, questions may be asked to students, such as: What led them to present this alternative as the best for decision-making? What are the consequences of this decision for the organization and its stakeholders?

The students' positioning may even reveal different profiles of coping with the problem, that is, those students most likely to accept and those most resistant to change. At that moment, the professor may invite students to reflect on their decisions, revealing how possible beliefs, inclinations, or predilections can affect the different decisions of their personal and professional life. 


\section{OUTCOME OF THE CASE}

Consepe met on May 11, 14, and 18, 2020, approved the resolution that provisionally regulates the supplementary period, and allowed remote teaching and learning activities to be carried out for graduation, from June 8 to August 14, 2020. Therefore, the decision made by PRG was to continue the proposal for a supplementary period with remote activities. Therefore, several actions were taken:

a. Implementation, configuration, and availability of a new AVA, called Moodle Classes, with a more modern appearance, improving the usability of the AVAs available until then by the institution;

b. Conducting training for professors and students to use Moodle Classes, in addition to publishing tutorials and manuals;

c. Development of integrations between Moodle Classes and the institution's academic management system (Sigaa), allowing the automatic inclusion of students enrolled in AVA; d. Provision of a questions portal, which functioned as a central channel, so that the academic community could register their doubts and get answers; in addition, communication channels via WhatsApp were created to make communication more agile;

e. Organizing meetings in teaching centers to clarify the proposal, which allowed the involvement of different institutional actors in the change process;

f. Flexibility of teaching activities, for example, allowing them to share disciplines and record training in their workloads.

The offers of classes in the supplementary period allowed more than 18 thousand students to be involved in remote education activities, which corresponds to about $76 \%$ of the amount of students when considering the average of the last regular periods. In addition, UFPB served as a reference for other public HEIs, due to its avantgarde character in the ability to adapt in times of crisis such as COVID-19. After the start of the supplementary period, PRG began the planning for a new remote period.

\section{REFERENCES}

Daft, R. (2008). Organizaçôes: Teoria e projetos. (9a ed.). São Paulo: Cengage Learning.

Dias, R. (2013). Cultura organizacional: Construção, consolidação e mudanças. São Paulo: Atlas.

McShane, S. L., \& Von Glinow, M. A. (2014). Comportamento Organizacional. (6a ed.). Porto Alegre: AMGH.

Ramos, M. M. A. (2017). Empreendedorismo, inovação e mudança organizacional. (v. 3). Coimbra: Actual Editora.
Robbins, S. P. (2015). Lidere e inspire: A verdade sobre a gestão de pessoas. São Paulo: Saraiva.

Universidade Federal da Paraíba (2019). Histórico. Retrieved from https://www.ufpb.br/ufpb/menu/institucional/ apresentacao/historico

Universidade Federal da Paraíba (2020). Pró-Reitoria de Graduação. Retrieved from http://www.prg.ufpb.br/ 


\section{Authorship}

\section{Diana Lucia Teixeira-de-Carvalho*}

Universidade Federal da Paraíba, Centro de Ciências Sociais Aplicadas, Departamento de Administração

Cidade Universitária, s/n, Castelo Branco, 58051-900, João Pessoa, PB, Brazil

E-mail address: diana.carvalho@academico.ufpb.br

(D) https://orcid.org/0000-0001-6454-8604

\section{Jose Jorge Lima Dias Junior}

Universidade Federal da Paraíba, Centro de Ciências Sociais Aplicadas, Departamento de Administração

Cidade Universitária, s/n, Castelo Branco, 58051-900, João Pessoa, PB, Brazil

E-mail address: jorge.dias@academico.ufpb.br

(1) https://orcid.org/0000-0003-4381-1930

\section{Ana Carolina Kruta-Bispo}

Universidade Federal da Paraíba, Centro de Ciências Sociais Aplicadas, Departamento de Administração

Cidade Universitária, s/n, Castelo Branco, 58051-900, Joáo Pessoa, PB, Brazil

E-mail address: ana.kruta@academico.ufpb.br

(D) https://orcid.org/0000-0002-0664-8575

* Corresponding Author

\section{Funding}

The authors reported that there is no financial support for the research in this article.

\section{Conflict of Interests}

The authors have stated that there is no conflict of interest.

\section{Plagiarism Check}

The RAC maintains the practice of submitting all documents approved for publication to the plagiarism check, using specific tools, e.g.: iThenticate.

\section{Authors' Contributions}

$1^{\text {st }}$ author: conceptualization (equal); investigation (equal); project administration (equal); supervision (equal); writingoriginal draft (equal); writing-review \& editing (equal).

$2^{\text {nd }}$ author: conceptualization (equal); investigation (equal); project administration (equal); supervision (equal); writingoriginal draft (equal); writing-review \& editing (equal).

$3^{\text {rd }}$ author: conceptualization (equal); investigation (equal); project administration (equal); supervision (equal); writingoriginal draft (equal); writing-review $\&$ editing (equal).

\section{Copyrights}

RAC owns the copyright to this content.

\section{Peer Review Method}

This content was evaluated using the double-blind peer review process. The disclosure of the reviewers' information on the first page, as well as the Peer Review Report, is made only after concluding the evaluation process, and with the voluntary consent of the respective reviewers and authors.

\section{Data Availability}

All data and materials have been made publicly available through the Harvard Dataverse platform and can be accessed at:

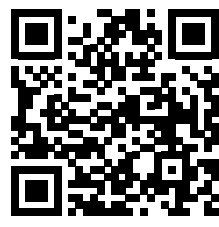

Diana Lucia Teixeira-de-Carvalho; Jose Jorge Lima Dias Junior; Ana Carolina Kruta de Araújo Bispo, 2021, "Replication Data for: Our calendar stopped! The organizational change at UFPB due to COVID-19", Harvard Dataverse, V1. https://doi.org/10.7910/DVN/EY3NJY

RAC encourages data sharing but, in compliance with ethical principles, it does not demand the disclosure of any means of identifying research subjects, preserving the privacy of research subjects. The practice of open data is to enable the reproducibility of results, and to ensure the unrestricted transparency of the results of the published research, without requiring the identity of research subjects. 